\title{
Muslim Girls’ Experiences in non-Muslim Schools of Brisbane
}

\author{
Huma Kanwal* \\ Griffith University, Brisbane, Australia \\ *Corresponding author: huma.kanwal@canberra.edu.au
}

Received January 19, 2015; Revised March 10, 2015; Accepted May 07, 2015

\begin{abstract}
Living conditions of Muslims have changed in the Western world. Many studies have found that after the incidents of September 11, 2001, Muslims all over the world, especially in the Western world have had to deal with the backlash of these events. Australia has not been isolated from this backlash. In this paper I explore the lives of 10 young Muslim girls who are 13-19 years of age and going to non-Muslim schools of Brisbane to find out their school experiences. In this paper I explore the school experiences of young Muslim girls to find out that at what extent these girls are struggling to negotiate their personalities while living in a non-Islamic society. Furthermore, the paper will highlight the issues of racism that has been faced by Muslim students in some of the Brisbane schools on the daily basis.
\end{abstract}

Keywords: muslims, girls, high schools, racism

Cite This Article: Huma Kanwal, "Muslim Girls' Experiences in non-Muslim Schools of Brisbane." American Journal of Educational Research, vol. 3, no. 5 (2015): 643-651. doi: 10.12691/education-3-5-18.

\section{Introduction}

This paper discusses in detail one of the most dominant themes that is emerging from a larger study that has sought to capture the lived school experiences of young Muslim girls in a number state schools of Brisbane. The larger project has found many others factors influencing the lives of young Muslim women studying in nonMuslim schools. This paper draws on the data around issues of intolerance of Muslim population as experienced by the participants.

Race is moral, intellectual and political issue like education (Syer, 1982). Syer (1982) identified many factors that seek to explain why and how racial discrimination is undertaken but most notably he found that it often took place unintentionally. He claimed that unconscious racism often arises where religious or subcultural sensitivities are overruled. He calls the categories of racism as 'deterministic' and atomistic uses a framework where there a number of key approaches to consider. First, a deterministic approach to see a poor academic performance as unavoidable consequence of personality, or of poverty or of inferior genes.Second, an atomistic approach is similar to the deterministic approach but, it explains phenomenon in relatively narrow terms. The need to understand the complex relationships that make up a society as a whole is ignored. He appalled at the situation whereby a child's poor academic performance is judged by his poor ability to learn. Sadly, such an approach fails to see the relationship between a child and a society where she/he grew up. No one knows how that child is treated as an infant and what kinds of experiences he/she had in school. Syer calls a wider, more complex framing in which there arerelationships among variable as being the woods whereas atomistic thinking sees only the trees. In this paper I will explore that how Muslim girls face such these various approaches and how wider relationships are perceived in their context. The focus of the papers is to discuss the experiences of young Muslim girls as they face and deal with racism in schools.

\section{Backdrop of Muslims in the World and in Australia}

What are the experiences of young Muslim girls in the non-Muslim schools of Australia? What are the factors or influences that help them or not to integrate with her peers and teachers? What kind of back lash are they facing after the international incidents of 9/11, 7/7 London Bombings 2005 and Bali Bombing 2005? These questions are a part of the lived experiences for some migrants in Australia when 'The War against Terror' started globally. Fethi and Trembath(2005) have found that political events, especially $9 / 11$ have changed the ways Arab-Australians are treated by some sectors of the community. The students who have participated in Fethi and Trembath's(2005)study have asserted that their existence have become synonymous witht error and threat. The girls, especially who are visible Muslims (wearing headscarves), become victim of negative attitudes and hatred (Fethi Mansouri \& Anna Trembath, 2005).

The impact of being visible and not part of the dominant culture was borne out in the events of France in the mid-2000s. Muslim women's freedom of choice was challenged when the wearing of the hijab was banned in 
French schools for the first time. According to Laurence and Vessie(2006), the French senate approved a bill in March 2004 that forbade the existence of "ostentatious religious insignia" in primary and secondary public schools. Studies by Keaton (2005) and Laurence and Vessie (2006) showed that while this law applies to all religious symbols it was mainly targeted at French Muslim women. This same debate about the wearing of the hijab began in Australia soon after 2004. Maiden \&Lipman(2005) wrote of the day when discussion about the wearing of the hijab began in Australia. On August 26, 2005 the in Australia, started when Conservative Coalition MPs Sophie Panopoulos and Bronwyn Bishop both publicised their opinions that the hijab should be banned in Australian schools. They defended their opinion by asserting that the majority of young people believe that the wearing of the hijab is merely an act of rebellion on the part of Muslim girls, over and above anything else.

Moreover, Prime Minister, John Howard's sceptical comments on the Muslim community on September 2006 on talkback radio; 'a small section of the Islamic population is very resistant to integration' become contentious among Australian Muslims. He further claimed that Muslim men are not liberating their women, they are not trying to learn English quickly, and thus, they are not adopting Australian values (Kabir, 2007). To recapitulate, global events in conjunction with some Australian politicised incidents resulted in affecting the lives of Muslim youth negatively.

In this paper, I draw on a selection of the literature related with racism faced by Muslim youth and particularly Muslim girls. Through this review I seek to develop an understanding of the ways in which young Muslim girls experience aspects of the Australian state school system. This paper discuss the challenges Muslim youth, particularly young Muslim girls, face when they cross the borders of their culture and religion by stepping into the mainstream Australian society where there are vast contrasts between the two worlds. I have explored how they have been judged by their appearance and consequently become victim of unconscious racism. Then, I discuss the research methodology, followed by the examination of the school experiences of these ten participants. In the last section of this paper, I discuss how these students are experiencing Australian school system and how their educational experiences could be enhanced. In the following literature, the terms 'racism', 'discrimination', 'prejudice', 'negativity' and 'misconceptions', 'stereotypes' are commonly used to describe the negative attitudes of masses towards minority groups. Australia and Muslims.

Australia is a secular, democratic multicultural society with a common law tradition. Perhaps its key feature here is the cultural secularity of Australia and the absence of a dominant religious tradition, despite the privileged historical position of Anglicanism (Turner, 2013). In a society where commitment to religion is often 'lukewarm', taking religion seriously looks peculiar (Turner, 2013). Even so, Australia has adopted policy of Multiculturalism in 1976 and welcomed people from different culture and religion. It was the time when Muslims from all over the world migrated to Australia in large numbers. Australia expects immigrants to 'integrate' with their culture and norms (Poynting \& Mason, 2007). The series of incidents after 9/11 including Bali Bombing, London Bombing 2005 and Madrid 2004 has affected the lives of Muslims around the world including Australia (Yasmeen, 2008).He further said that Muslim men are not liberating their women, they are not trying to learn English quickly, and thus, they are not adopting Australian values (Kabir, 2007).

\section{Muslims: The Excluded Community in Australia}

Muslims community is the most socially excluded community in Australia and among them Muslim women and youth are particularly excluded (Abdalla, 2012). Many studies have found that existence of Muslims in Western World have become a question mark after the Incidents of 9/11, Bali Bombing and London Bombing, 2005 (Australian Human Rights Equal Opportunity Commission, 2004; Mansouri \& Wood, 2008; Omar, 2007; Poynting \& Mason, 2007). The exclusion of Muslims from the Australian society is quite apparent in the number of cases of harassment and discourse on Australian values (Yasmeen, 2008). Yasmeen informed that the Muslims are facing increased exclusion from mainstream Australia. She also reported that Muslims think that they can be both Australian and Muslims at the same time but it seemed not accepted by the wider community (Yasmeen, 2008). Omar (2007) found that Muslims like to adopt only those cultural aspects of mainstream culture that are compatible with the Islamic values for example harmony and friendliness, the idea of multiculturalism, respect, a rational way of analysis, open mindedness and a sense of belonging. At the same time Muslims completely reject those mainstream cultural norms that are contrary to the Islamic values and teachings. For example: sex before marriage, eating pork, drinking alcohol and wearing sexually explicit clothing (Omar, 2007).

Australian state and private schools promote multiculturalism and celebrate the diversity of students from ethnic backgrounds and religion different from mainstream Australian society is part of a multiculturalist agenda to add this diversity of culture and religion into the school curriculum(Ata, 2007). Mansouri and Kamp (2007) argued that though this celebration of diversity that there are positive effects on Australian economy but at the same time it can be very challenging for the educational authorities to add this diversity into school curriculum to develop multicultural educational system. While there has been an implicit goal to celebrate multicultural diversity, it should be noted that in the entire history of the Australian curricula, these elements have never been fully integrated (Ata, 2007). Consequently, this has led, in general, to little knowledge within the mainstream Australian community about other cultures and religions, especially about Muslims.

\section{Racism against Muslims}

While there has been a concerted effort from education system to integrate and celebrate multiculturalism into the school sector, there have been other sectors of the public sphere where this is not the case. The western media has 
played a major role in spreading a pejorative depiction of Islam and Muslims, leading to a negative backlash against the Muslim world. Following the events of 9/11, 2001, Australian Muslims also suffered the consequences of this backlash from the media (Akbarzadeh \& Smith, 2005; Manning, 2003; Fethi Mansouri \& Anna Trembath, 2005; Poynting, Noble, Tabar, \& Collins, 2004; Vahed, 2008).

In Australia, the adverse depictions of Muslims in the media resulted in a trickling down effect in the educational system. Many Muslim parents were extremely concerned at the manifestations of racism against their children in schools that adversely affect their children's educational outcomes (Mansouri \& Trembath, 2005). A report titled 'Isma-Listen' by the Human Rights and Equal Opportunity Commission (HREOC) (2004) found that Muslim women and girls who wear the hijab (or headscarf) in schools also suffer because of the religious symbols they wear. Furthermore, as the majority of Muslim parents have expressed, their greatest concern was to help their children to maintain their cultural identity, their high moral standards, the performance of their religious practices and their native language (Clyne, 2000). Australian Muslim youth, especially women, are facing challenges in competing with mainstream Australians (Mansouri \& Wood, 2008), and Muslim schoolgirls often face prejudice and discrimination because of their religion and colour (Poynting, 2002). However, Omar (2007) found that discrimination by the wider community is made basically on the base of religion. He has found that black skin colour is not a major problem in Australia, and is of the view that black colour is a source of respect in Australia because, he contends, many Australian people are attracted towards the appearance of black-Americans.

Australian Muslims are one minority group against whom discrimination has been maximised, however negative stereotyping and discrimination is certainly not a new phenomenon (Poynting \& Mason, 2007). Since 1912 Muslims have been considered as the 'Other' and their existence was considered a threat to Australians' cultural and societal values (Poynting \& Mason, 2007). In the last decade, the Australian Muslim community has faced vilification and intolerance (Kabir, 2007). According to Poynting and Mason (2007), Australian Muslim immigrants and their families have been faced with racism, vilification and accusations of criminalisation since 9/11, 2011. They also experienced the same hatred and racism a decade before the Gulf War against Iraq in 1991. Therefore, from a historical point of view, some of the Muslims in Australia have confronted considerable political and cultural hindrances in their struggle to completely integrate into Australian society (Mansouri \& Wood, 2008). A study by the Human Rights and Equal Opportunity Commission (2004) found that few Australians had a low level of religious and cultural tolerance, in spite of being a multicultural society.

After the 9/11 terrorist attacks, many Australian Muslim communities were vilified because of their Islamic identity (Vahed, 2008). Vahed claims that this harassment increased in Australia after the Bali bombings on 12th October, 2002, where 202 people, including 88 Australians, were killed by Indonesian Muslim terrorists (Vahed, 2008). As Poynting et al. (2004) also note, there has also been an increase in negativity against Australian Muslims, in part due to the aftermath of September 11,
2001. As Kabir (2007) identified, in some ways a religious group can become the victim of resistance from the wider society when the group is considered to be a direct or an indirect threat. She argues that Muslim Australians have become the 'current enemy' because of the perceived international threat of militant Islam.

Browning and Jakubowicz (2003) affirm that after 9/11 and the Bali bombing in 2002, the negativity against Muslims increased as a result of 'Islamophobia'. Dunn, Klocker \& Salabay(2007) also note that this negativity has badly affected the lives of Australian Muslims, and increased Islamophobia in the wider community. Poynting et al (2004) assert that Arabs and Muslims have become victims of some sensationalist and opportunistic media and have been confronting vilification for deeds they have not committed. Furthermore, they found thatracism and vilification against some Muslims existed in the Australian society but was exacerbated after the incident of September 11, 2001.

A study by Mason (2004)found that Islamophobia does indeed exist within Australian society. His study also shows that one in eight people admitted that they are prejudiced against Muslims. However, scholars (Pedersen, Aly, Hartley, \& McGarty, 2009)identify the fact that it is the media's negative way of reporting controversial events which have influenced negative stereotyping of Muslims The studies of Aly (2007); Issues Deliberation Australia (2007) and Griffiths \& Pedersen (2009) have linked the media with anti-Muslim prejudice. These studies found that the media's negative portrayal of Muslims and Islam has contributed to the vilification of Muslims by few members of Australian society.

Hassim \& Cole-Adams (2010) have explained that other misconceptions about Muslims include statements that they all are considered as terrorists, they are against democratic values, that women are inferior to men, and that Islam is intolerant to other religions. Moreover, Muslims look, dress and eat differently, they do not want to integrate into Australian mainstream society and they want to implement their own Sharia law (Islamic law) in society. As Akbarzadeh et al. (2009) discuss, racism and prejudice against Muslims exists among non-Muslims because they know very little about the real teachings of Islam. Interaction with the Islamic community is often non-existent; subsequently Muslims became the victims of propaganda, prejudice and ignorance. A survey conducted by Issues Deliberation Australia (2007) found that 50\% of Australians said that they never have had any kind of interaction with Muslims and only 20\% said that they have interaction with Muslims on a daily basis. In the same survey, it is found that the majority of Australians (71\%) do not want people from the Middle East, Asia or other Muslim countries to immigrate to Australia. Rather, they favoured immigrants from English-speaking countries or from other European countries (Issues Deliberation Australia, 2007). In relation to this current discussion, a report presented by the Human Rights and Equal Opportunity Commission (2004) found, after a survey conducted in Sydney and Melbourne in 2003 on 186 Muslim and Arab Australians, that approximately 87 per cent of Muslim respondents had experienced vilification, abuse or racist violence after the attacks in September 2001. 
Invariably, the pejorative representations of Islam and Muslims in Australia had an impact on the experiences of Australian Muslim students, as was discovered through a research study conducted by Ata (2007). Usinga survey in Victoria administered to 550 students in Years 10 and 11; Ata found that more than half of the students indicated that 'Muslims are terrorists' while other students believed that Muslims 'behave strangely’.

\section{Muslim Women, Hijab and Racism}

As indicated in a study by Ata (2007), young adults indicated that they thought the Muslims behave strangely. In some cases, the overt appearances of Muslim women who wear the variations of dress codes (ranging from head scarfs to the full hijab) make them more visible to the public.

According to Runnymede (1997), it is quite evident that those women who wear Islamic dress in the wider community suffer from amplified violence, prejudice, vilification, exclusion and discrimination. Issues Deliberation Australia (2007) found that young Australian women now wear the hijab publically as symbol of their identification and to show pride in their faith.

Study of Vahed(2008) found that it is because of the headscarves of the Muslim women that tend to give impression to some non-Muslims to judge them wholly. His study argued that some non-Muslims question some Muslims in a very awkward manner. His research into young Muslim women in Brisbane uncovers stories of their lives in the wider community. One Muslim female participant of Vahed's research (2008) related her experience at a local store. She wore a t-shirt printed with the words 'Have Faith' on the front. Her understanding of the meaning of these words was that she should have faith in one's own abilities, but unfortunately she was confronted by a middle aged white woman shouting at her saying, 'What faith? You bloody Muslims think you will convert us! Who would ever accept such a stupid religion?' The respondent (wearing a hijab) said that she was so shocked to hear this that she could not even reply. These kinds of incidents have yielded a mixed response from young women (Vahed, 2008). According to Yasmeen (2002), the prevalent negative preconceptions about Muslims have provoked some Muslim women to become active in the public sphere where they have begun to form both formal and informal associations to help, represent and support other Muslim women.

Several research studies have found that young Muslim women in Australia are more likely to become victims of racism and vilification than males (Human Rights and Equal Opportunity Commission, 2004; Kabir, 2009); and that young Muslim girls are subject to stress both in the public and the private domain (Kabir, 2009). In 2004, the report cited earlier and titled 'Isma-Listen' by the Human Rights and Equal Opportunity Commission (HREOC, 2004) reported that in Australia there is much discrimination in terms of race and religion against women. The report contains many pages detailing physical violence, offensive comments and biased behaviour by non-Muslims against Muslim women, specially young Muslim women are more likely to face it. Issues Deliberation Australia (2007) noticed that Muslim women wearing the hijab have to tolerate negative comments and behaviour by mainstream society.

Imtoual (2006) illuminated the way in which Muslim schoolgirls are categorised into two different types. She argued that the debate around the wearing of the hijab in schools carried substantial implications for young Muslim women attending Australian schools, and equally for their educators. These young women have been categorised in different terms. For example, those women who wear the hijab are considered to be defiant, backward, against freedom, recalcitrant, barbaric, servile and oppressed, while those who are not wearing the hijab are categorised as being modern, freedom loving, acceptable, and feminist. Imtoual (2006) further elaborates that neither of these categories actually describes the school experiences of young Muslim women, instead it merely intensifies the religious racism directed at these students. Hence, there arises the probability that the majority of students and teachers hold the same opinion of those Muslim women who wear the hijab and this probability could give rise to a culture that views hijab-wearing Muslim women with suspicion.

Gunel (2007) illustrated three prevalent features that affected Muslim girls' experiences in school; these are racism, sexism and xenophobia. Further studies by Elnour\& Bashir-Ali (2003) and Zine (2006) identified three dominant themes regarding the problems faced by Muslim girls in schools. As they illustrated, the initial conflict takes place with issues of family expectations, which include early marriage and their responsibilities within the house, followed by the decision to wear the hijab or not, and family restrictions in their relations with the opposite gender.

In the preceding sections, I have provided an overview of the current themes emerging from the literature about the experiences of Muslims, most particularly, Muslim women, as they negotiate their life-worlds and the disruptions they experience as they face often competitive experiences with non-Muslims. The literature is quite diverse but there is limited, if any, research that carefully examines the experiences of young women in schools. In this study, I have explored the lives of 10 young women who attend non-Islamic (or mainstream) schools, in order to document some of their experiences. While there are many themes emanating from this research, the issues around racism were highly visible.

\section{Methodology}

This qualitative research aimed to obtain intricate details about a phenomena such as feelings, sentiments and thought-provoking processes that are difficult to extract or understand with the help of more traditional methods (Strauss \& Corbin, 1998). Transcendental Phenomenological approach was used to explore the lived experiences of Muslim teenage girls in non-Muslim schools of Brisbane, Australia. Grounded theory has been as a tool to analyse the data.

The use of this phenomenology helped researcher to probe into the participants' daily experiences in nonMuslim schools, in order to explore the phenomenon of border crossings. This methodology provides the necessary tools in the conduct of this study. The 
phenomenon of crossing the borders of culture and religion and stepping into an entirely different culture could only be explicated while remaining in the confines of transcendental phenomenology.

Accordingly, semi-structured, in-depth interviews were conducted for this study ((Berg, 2006). This study interviewed ten Muslim girls who are attending three different non-Muslim schools in Brisbaneand attending High School A, and are going to High School B; and are going to High school C.

Table 1. Participants and their School type

\begin{tabular}{|l|l|l|}
\hline School A & School B & School C \\
- Alia (aged 16) & • Rihanna (aged 18), & • Eman (aged 14) \\
• Salma (aged14 & • Mahwish (aged13), & • Khalida (aged 14) \\
& • Saman (aged 15) & \\
& - Sofia (aged 18), & \\
& - Hafsa (aged 16), & \\
& • Maria (aged 14) & \\
\hline
\end{tabular}

The students were volunteers for the study and were recruited through the local Mosques. This opportunistic method for data collection was one way to recruit participants that allowed access to students outside the formalities of recruitment through the school system.

The reason of using semi-structured format with openended questions was because the use of observation only would not have exposed the experiences of these girls. In depth interviews helped the researcher to gain comprehensive information about informants' beliefs, behaviour and experiences. In depth interviews also help researchers seeking to discover new issues in detail (Boyce \& Neale, 2006).

Each participant was interviewed once, and each interview lasted from 30 to 40 minutes. Seven interviews took place in a mosque, one interview took place in a public library and two interviews were conducted at the homes of participants. Two Palestinian sisters were interviewed at their home, as this was more comfortable for them. One participant who was interviewed at the library was from Kenya. One out of the seven girls who were interviewed in the mosque came from Syria, and the remaining six girls came from Somalia. The participants were made to feel comfortable, so that they could speak freely and share their experiences easily. The interviews were started informally by asking participants their ages, names and countries of origin. The rest of the interview consisted of questions related to their experiences in nonMuslim schools and about their likes and dislikes. However, the interview questions were broad enough to provide room for the participants to freely express their opinions and talk about their experiences. The interviews were tape-recorded and were transcribed verbatim. Analysis of the interviews was through themes as per grounded theory. One of the most prevalent themes was racism.

The interview questions were open-opened, below is the list of some of the questions that were asked to the participants when they talked about the 'racism' and other factors that they are experiencing when they are in the school.

Table 2. Interview Questions

Interview Questions

Q1. What do you think being in a non-Muslim / Muslim School, where everybody is from different backgrounds?

(b) How do you negotiate your Muslim identity when you are at school?

(c) What are the challenges you face when you have to work with your Muslim culture in a non-Muslim/Muslim setting.

Q2. How does your school cater for your Muslim beliefs?

(b) How might your school better care for your Muslim beliefs?

Q3. Tell me about your teachers and school's management behaviour towards you and your Muslim faith?

(b) Do you have any concerns that you want to share?

\section{Findings}

\subsection{Racism, Discrimination and stereotyping in Schools}

The majority of the participants of this study talked about racism and discrimination that exists in their school. Experiences of racism were reported by the respondents on the grounds of religion; namely being Muslim, and also on the basis of colour; (six participants are Somali girls who had very dark skin colouring). The girls were very articulate in naming colour as being a salient factor in their negative experiences. However, it was often difficult to untangle issues of race from religion in terms of the othering being experienced by the young women. As such, the concept of othering is most powerful in theorising the experiences of the participants.

In the following sections, I elucidate some of the issues around racism and discrimination found in the responses of the participants. I draw on these comments to highlight the process of 'othering' that became evident in the study. For the young women, many of them were positioned through the actions (verbal) of their peers in the school. They were made to feel somewhat 'different' from the other students based on elements of either race and/or religion.

One participant commented that if an indigenous student were to suffer discrimination then action would be taken as the school has a strict policy and punishment is effected to the offending student. However she also commented that she believes that there are no policies for Muslims that can protect them from being discriminated against. Hafsa (16) mentioned several incidents that happened to her at her school and said that she felt that the school should stop discrimination. She asserted that Muslim students have been discriminated on the daily basis but there is no one in the school who can speak up for them. She said that when she saw some younger boy or girl being discriminated she can relate to them but she could not do anything to protect them. She said she is more conscious of her surroundings than her other Muslim friends because she feels for those who have been 
discriminated against. She told them that such behaviours should not be considered normal as a feeling of being hated could ruin the confidence of an individual. She narrated that the rules are different for different ethnic groups so that the processes of othering were quite apart depending on the background of the students. She asserted that once in her class an Aboriginal girl was discriminated by one of the boys of the class and the boy has to "face the music”. He was suspended from the school for few weeks with the warning of expelling from the school if repeated the same act.

"I remember, there was an Aboriginal girl in my class and she has been discriminated by calling with a bad name (don't remember what exactly he said) by one of the boys of our class, and the school has taken big reaction of it, the boy has been suspend for a month and the principal said how come you call bad name to a fellow of yours...But Muslim students have been discriminated on daily basis, but no one is there to protect them from this humility...if students know that they are going to be in trouble like if the discriminate aboriginal, they would stop mucking around Muslims...(Hafsa, 16)".

Hafsa then shared one of her personal experiences where her group of Muslim friends was discriminated against because of their religion.She reported that she feltthat nobody in the school's administration cared about their feelings and they did not take any action. This experience highlighted the stark differences in experiences based on being Muslim or Aboriginal. For Hafsa, this difference was quite startling. She narrated that she and her group of Muslim friends were having lunch in the café when a bunch of boys showed up there and bullied them by calling them 'terrorists'. She said they tried to ignore what boys are saying but one of their friends started fighting back and meanwhile a teacher appeared on the scene and she did not take any action against them and just asked the boys to leave.

"I remember another incident that happened when me and my few other Muslim friends were sitting in canteen and a bunch of boys came and shouted 'TERRORISTS'...few of my friends just ignored and few started yelling, my one of friends started saying oh you red neck, you invaded Australia and stuff...and meanwhile a teacher came and she just said calm down boys and go to your classes... we were just sitting like stupid's, and if I go back to that Aboriginal girl, how the school has took action but for us, there is nobody who can shut their mouths in spite of ourselves getting involved in it...it's so unfair! No teacher is there to stand for us!" (Hafsa, 16).

What these two comments highlight is the difference between being Aboriginal and being Muslim as perceived by Hafsa. She perceived these two experiences as being unequal and unfair in terms of how the school dealt with issues of race. She gave the impression that if an Aboriginal student is discriminated then there are rules in the school that could protect them but for Muslim students the school do not have the same rules.

What is more concerning in terms of racism, is that the Muslim students who come from Africa experience two aspects of othering - first on the basis of religion and then on the basis of colour. This doubling of othering compounds the experiences for the young African Muslim women.

Students from Africa who are also Muslims have been discriminated on both counts. The process of othering, as made explicit by the participants, was difficult for students such as Khalida (age 14) to comprehend as to why one human being wouldact towards other human beings in the ways that she has experienced and/or observed. Khalida spoke about the stigma that othering creates where she commented that black people are often described through a range of pejorative terms such as being thieves or involved in criminal acts because of them being different from mainstream Australia. The process of labelling the other in perjorative terms ensures that they are positioned as different from the mainstream.

"I don't like when people always associate bad things with Islam. I don't understand why people do this, I have been discriminated by my colour just today, there was two boys one Asian and one Australian, Asian boy said hey I am black...other guy say how you say that you are black? Asian boy said because I just stole something as you know black people stole things.... they both laughed...I was just like do I stole something??? And they just looked at me and pass through me with that bad smile on their face... (Khalida, 14).

Using the phenomenology method has helped the researcher to listen deeply to each and every participant and understand their experiences from their perspectives. Students like Sofia and Hafsa who both attend High School B were the only participants who stated their complete dissatisfaction with their school. Time and again they expressed to the researcher that they believe that their school does not care about Muslims students because they may be seen as very demanding students, especially with regard to requests for a different school uniform, different food and always asking for a prayer room.

Sofia shared one big incident that she was involved with in the last year of her school she became involved in a fight with another student. She said she was never involved in fights and nor did she talk loudly in the school but once she has been forced to do so, but she said she had to pay for the fight because there was no one who would listen to her side of the story, only the other girl's version of the story.

"I don't try to get into fights... (laugh)...to be very honest I get into fight with a non-Muslim girl, she called me towel head...mop head...and all this annoying stuff when I was not even arguing with her, me and her friend were arguing on some issue and she came from her way to fight with me, she was of my age but in lower grade (grade 11). She just start yelling hey towel head I am talking to you...hey mop head listen to me...I was ignoring to her and said shut your mouth and don't be rude I am not talking to you... and then she didn't stop...I get mad and put off my scarf and turned to her and said dare now to say anything annoying to me...we both start yelling at each other and then she suddenly give punch in my stomach, that girl was big girl and I am in front of her like tiny...she was chubby and gigantic!!! I couldn't even breath for a second... and I get so mad that I just run to her and pushed her back and hit her, hit her and hit her...It was out of my character...I never used to be in fights but 
this one day.... oh God! It was so embarrassing!!!Then all teachers came there and tried to take me off from this fight but I was saying I am not going to leave her she said towel head to me and stuff...

She further narrated that how the prosecution started later and she was the one who everyone was thinking that at fault.

"And then that girl starts crying and start doing drama... and now the prosecution session started, I was one to be blamed as I am in year 12...I tried to explain to them that look at her and look at me? Can I indulge myself to fight with a gigantic figure...she was the one who herself involved in this fight"

Sofia narrated that the fight was started by the other girl and whatever she did was in reply. She said she did her self-defence by hitting and pushing her back. Also, she felt that the girl had been given the advantage of being in lower grade. There were few teachers who have supported her including her drama teacher. The teacher accepted that it is an act of discrimination and should be condemned.

It was self-defence! She beat me first and I beat her back...that's it. She is in lower grade but don't give her advantage on this base...My drama teacher backed up me, she said on my behalf that It is discrimination... and there were teachers who were backing her up...I was yelling that I don't come to school to be discriminated...and stuff...she called me towel head, I didn't say her blonde, blue eyes, fatty or white...

Furthermore, she talked about the behaviour of the deputy Principal over this case. Her experience in this matter made her to say that the deputy principal was racist since she was the only one that received punishment. He suspended her for two weeks and later sent her to behaviour management classes for two months when the OP (Over-all Position) tests were taking place. She said:

"The deputy Principal handed over this case and he was a racist! I hate him more than anyone...he suspended me for two weeks.... internal suspension for one week and I have to write to behaviour management, I have to go to behaviour management school for two months... I am sitting at home for two weeks doing nothing... and that white girl...nothing has been said to her! They give her the world treatment...they think I have really beaten her badly...but can't they see how can I beat such a gigantic girl...they provide her all expenses if she met any medical treatment, but they didn't care that I have also been beaten and I might also be hurt..."

The incident shows that Sofia was badly shattered by the decision made by the deputy head and she felt that she was not been treated equally. She kept on repeating that it was quite obvious from the girl's appearance that she was a huge girl in comparison to her then how could she even knock her down. However, it is seen that not everyone was against her, she found support from a lady (nurse).

But there was a nurse in my school, she was very tight to me, as I also want to be a nurse and she used to help me quite often, I told her my entire situation, she said you know what? This is discrimination, and then that nurse writes a formative letter with my name (as I don't want her to be in trouble) with all happening, and I write in letter that I don't want that any other Muslim girl will be treated in the same way in future, like the way I am...when school administration come to know about this letter, and come to know that actually it wasn't my fault...they apologized me! But what is the meaning of this apology if they have wasted my precious time and bad name has come with me...I just say please make sure that no other Muslim girl will be again in my situation...It was all dramatic!!! It was so bad..." Sofia (18).

Sofia also said that this fight might be just be a regular fight in the school; however this fight left many questions in the Muslim students' minds as to why only they have not been trusted and why nobody seems to understand that Muslims students could also be right. She said that in this fight there was fault on both sides and that they both misbehaved and beat each other; however punishment was only given to a Muslim student.

These examples provide some insights into the experiences of some of the Muslim girls in mainstream schools. These girls took quite a proactive stance against what they saw as discrimination. This study has revealed that of the girls who were unsatisfied with their school's handling of what they believed was discrimination; there are two types of responses that the girls displayed. For example Sofia was a girl who became defensive when she perceived that she was being discriminated against. In this instance, Sofia took overt action against her discrimination. In contrast, there was another approach among the girls. Students like Hafsa, Rihanna, Khalida and Maria seemed to expect to be discriminated against and decided to primarily involve themselves with their studies and ignore what was going on around her. Their approach was more about withdrawing from the practices and to be silenced. As can be seen from the comment from Hafsa below she focused on study and tried to make herself invisible to her peers. In doing so she avoids judgement by her peers.

"I am polite, I am quite most of the time, and I wore long skirts with jumper, everything that is long. I don't participate in swimming and sports, I just go to school for study, nothing else because I don't feel I am one of them, I tried to keep myself away from all those gossips...” (Hafsa, 16).

Rihanna took a similar non-confrontational approach and simply attended school even though she did not enjoy it and did not really engage with school.

"I didn't enjoy much in my school; I was going to school because I have to go" (Rihanna, 18).

What the girls have shown is that whilst they believe that racism occurs in their schools but they have chosen to deal with it in different ways. Whilst some of the girls adopted non-confrontational approach that protects them from being judged, like Hafsa, Saman, Rihanna, and Khalida, some of the girls accepted that it is all about studying in non-Muslim schools and simply do not care if someone shows a racist attitude towards them. Others do not care that what others say, like Salma, Eman, Maria and Mahwish. However just one girl, Alia, said she never confronted racist attitudes (except once, because of her hijab and she ignored it) towards her, in twelve years and she enjoys attending her school. On the contrary, another girl Sofia dealt with racist attitudes strongly by adopting a very defensive and aggressive attitude. She reported that when she was in lower grades (8, 9 and 10), she was very innocent and she felt that people just took advantage of that fact and discriminated against her, however when she became a bit more mature, in grade 11 and 12, she 
believed that there was just one way to stop racism if her school did not help her and that was to act defensively.

\section{Discussion}

Research studies by Gunnel (2007), Ata (2007) and Kabir (2009) and a report presented by the Human Rights and Equal Opportunity Commission (HREOC, 2004) found that Muslims can become victim of racism, especially young Muslim women. Some of these studies illustrate the fact that racism and discrimination exists in Australian schools (Ata, 2007) and Muslim girls become victim of it more so than Muslim boys. This study supports these studies as it has been found that most of the girls reported that they believed that they were subjected to racism in their schools, especially those students who were in the latter years of high school. This study found that some girls complained that there are no rules for them if they have been discriminated against, and some of the participants in this study took different approaches to deal with racism. Some of them such as Hafsa and Rihanna isolated themselves in order to escape, and some of them like, Maria, Khalida and Eman, seemed to accept that they may suffer discrimination because of their difference and do not care what others say about them or Islam. Sofia in particular, dealt with what she felt was discrimination defensively similarly to the participants of Imtoul's (2007) participants.

The findings of HREOC (2004) and Akbarzadeh et.al (2009) suggest that this racism exists in the schools and in society because very little is known about Muslims and Islam by non-Muslims. This study supports the findings of Akbarzadeh and HREOC, as all participants of this study said that their teachers and their peers know very little about them, and that this is the reason that that they have felt prejudged and discriminated against. All participants of this study asserted that the majority of Australian people appear to believe in what the media says about Islam and Muslims. They further stated that teachers should have a greater knowledge of Islam and Muslim culture and they should know that why they are fasting and why they are covering their heads and about other religious practices. This phenomenon again supports the assertion of Clyne(2006)that teachers should have an encyclopaedic knowledge of other cultures and religions.

The majority of the participants of this study talked about racism and discrimination that existed in their school based on their Islamic backgrounds. Six participants of this study were from Somalia, who reported that they suffered both racism and discrimination based on their colour and religion. This study revealed that the victims who suffered the most discrimination were those who were both black and Muslim. It was noted that participants including Saman, Alia and Salma whose complexions were fairer did not suffer the same level of discrimination. All of the participants who wear the hijab reported that they were discriminated against however the coloured girls who wore the hijab felt that they had suffered the most discrimination. The participants also reported that they felt that not all incidents of discrimination in their schools had been dealt with equally and that schools needed to have policies in place to ensure this happened. It would seem from this small study that the processes of othering are actively undertaken, particularly for young women who are visibly differenteither through their colour or their dress code. It appears from this small study, those young Muslim women who are more moderate in their dress code or look more like mainstream Australians, are less likely to experience othering than their peers who are visibly different.

\section{Conclusion}

In conclusion, the researcher argues that the Muslims face great challenges in Australian society when it comes integrate with their peers. Especially women, as they are easily identified by the host Western society because of the highly visible clothing of their Islamic dress including the headscarf. Muslim girls face racism and discrimination in the school and unfortunately there are no standard rules that can protect Muslims from this disgrace. Furthermore, the study reveals that these girls are committed to observe their lifestyle and beliefs and feel privileged to be living in Australia. The analysis of data reveals that whilst there is some support of Muslim students in non-Muslim schools in Brisbane, the respondents believe that there is still a lack of knowledge about Muslims and Islam that causes discrimination in their schools and that this needs to be addressed in non-Muslim schools. The findings also reveal that participants perceived that acts of discrimination against Muslim students were not treated equally. At the very least, the findings of the study suggests that most young Muslim girls in these schools feel restricted by the limitations of their culture and beliefs and therefore retreat from their peers and suffer a degree of loneliness.

\section{References}

[1] Abdalla, M. (2012). The Way Forward for Muslim Women: Reflections on Australia's social Inclusion Agenda In T. Lovat (Ed.), Women in Islam: Reflections on historical and contemporary research (pp. 135-147): Springer.

[2] Akbarzadeh, S., Bouma, G. D., Woodlock, R., Ling, R., Rahman, A., \& Russell, Z. (2009). Muslim Voices: Hopes \& Aspirations of Muslim Australians. Centre for Muslim Minorities \& Islam Policy Studies, School of Political and Social Inquiry. Faculty of Arts. Monash University.

[3] Akbarzadeh, S., \& Smith, B. (2005). The representation of Islam and Muslims in the media: The.

[4] Aly, A. (2007). Australian Muslim responses to the discourse on terrorism in the Australian popular media. Australian Journal of Social Issues, 42(1), 27.

[5] Ata, W. A. (2007). Moslem Arab Portrayal in the Australian Press and in School Textbooks. Australian eJournal of Theology, 19(3), 207-2017.

[6] Australian Human Rights Equal Opportunity Commission. (2004). Isma-Listen: National consultations on eliminating prejudice against Arab and Muslim Australians: Australian Human Rights and Equal Opportunity Commission.

[7] Bashir-Ali, K., \& Elnour, A. (2003). Teaching Muslim girls in American schools. (Women of the World). Social Education, 67(1), 62+.

[8] Berg, B. L. (2006). Qualitative Research Methods for the Social Sciences (6 ed.). Boston: Allan \& Bacon.

[9] Boyce, C., \& Neale, P. (2006). Conducting in-depth interviews: A guide for designing and conducting in-depth interviews for evaluation input: Pathfinder International Watertown, MA.

[10] Browning, J. A., \& Jakubowicz, A. (2003). What Can We Say About Racism in Australia? Racism Monitor Report: Discussion Paper No. 1. 
[11] Fair Go Australia \& Transforming Culture Research Centre, University of Technology Sydney.

[12] Clyne, I. D. (2000). Seeking Education: The Struggle of Muslims to Educate Their Children in Australia. University of Melbourne, Department of Education.

[13] Clyne, I. D. (2006). Seeking Education: The struggle of educating Muslim children in Australia. Unpublished PhD Thesis. The University of Melbourne.

[14] Dunn, M. K., Klocker, N., \& Salabay, A. (2007). Contemporary racism and Islamaphobia in Australia : Racializing religion. Ethnicities 7(4), 564-589.

[15] Griffiths, B., \& Pedersen, A. (2009). Prejudice and the function of attitudes relating to Muslim Australians and Indigenous Australians. Australian Journal of Psychology, 61(4), 228-238.

[16] Gunel, E. (2007). Understanding Muslim Girls' Experiences In Midwestern School Settings: Negotiating Their Cultural Identities And Interpreting Social Studies Curriculum. (Doctor of Philosophy), Ohio State University.

[17] Hassim, E., \& Cole-Adams, J. (2010). Learning from one another: Brining Muslim Perspectives into Australian Schools. National Centre of Excellence for Islamic Studies. University of Melbourne.

[18] Human Rights and Equal Opportunity Commission. (2004). 'IsmaListen: National consultation on eliminating prejudice against Arab and Muslim Australians'.

[19] Imtoual, A. S. (2006). They Don't Want Us To Practice Our Faith Young South Australian Muslim Women \& Their Experiences of Religious Racism In High School. Proceedings of the AARE 2006 International Education Research Conference.

[20] Issues Deliberation Australia. (2007). Australia Deliberates Muslims and Non-Muslims In Australia.

[21] Kabir, N. (2007). What does it mean to be un-Australian? Views of Australian Muslim students in 2006. People and Place, 15(1), 62-79.

[22] Kabir, N. (2009). The 2Rs - Respect and Responsibility: The Case of Australian Muslim Girls. Cosmopolitan Civil Societies Journal', 1(3).

[23] Keaton, T. (2005). Arrogant Assimilationism: National Identity Politics and African - Origin Muslim Girls in the Other France. Anthropology \& education quarterly, 36(4), 405-423.

[24] Laurence, J., \& Vaisse, J. (2006). Integrating Islam: Political and religious challenges in contemporary France: The Brookings Institute. Washington: DC.

[25] Maiden, S., \& Lipman, N. (2005). Scarves more rebellion than religion: Lib. The Australian, 26, 6.

[26] Manning, P. (2003). Arabic and Muslim people in Sydney's daily newspapers, before and after September 11. Media International Australia, Incorporating Culture \& Policy(109), 50.

[27] Mansouri, F., \& Kamp, A. (2007). Structural deficiency or cultural racism: the educational and social experiences of Arab-Australian youth. Australian journal of social issues 42(1), 87-102.

[28] Mansouri, F., \& Trembath, A. (2005). Multicultural education and racism: The case of Arab-Australian students in contemporary Australia. Deakin University.
[29] Mansouri, F., \& Trembath, A. (2005). Multicultural education and racism: The case of Arab-Australian students in contemporary Australia. International Education Journal, 6(4), 516-529.

[30] Mansouri, F., \& Wood, S. P. (2008). Identity, Education and Belonging: Arab and Muslim Youth in Contemporary Australia: Melbourne University Press.

[31] Mason, V. (2004). Strangers Within in the "Lucky Country": Arab-Australians after September 11. Comparative Studies of South Asia, Africa and the Middle East, 24(1), 233-243.

[32] Omar, Y. S. (2007). Australia's Muslims: experiences and expectations after September 11. Discussion Papers. Centre for Dialogue: A centre of La Trobe University 3.

[33] Pedersen, A., Aly, A., Hartley, L., \& McGarty, C. (2009). An intervention to increase positive attitudes and address misconceptions about Australian Muslims: A call for education and open mindedness. The Australian Community Psychologist, 21(2), 81-93.

[34] Poynting, S. (2002). Bin Laden in the suburbs: Attacks on Arab and Muslim Australians before and after 11 September. Current Issues in Criminal Justice, 14, 43.

[35] Poynting, S., \& Mason, V. (2007). The resistible rise of Islamophobia: Anti-Muslim racism in the UK and Australia before 11 September 2001. Journal of Sociology 43(61), 61-86.

[36] Poynting, S., Noble, G., Tabar, P., \& Collins, J. (2004). Bin Laden in the Suburbs: Criminalising the Arab Other. Sydney Institute of Criminology.

[37] Runnymede. (1997). Islamophobia a challenge for us all: The Runnymede Trust.

[38] Strauss, A., \& Corbin, J. (1998). Basics of Qualitative Research: Techniques and Procedures for Developing Grounded Theory: London: Sage.

[39] Syer, M. (1982). Racism, Ways of Thinking and School In J. Tierney (Ed.), Race, Migration, and Schooling: Thetford Press Ltd, Norfolk

[40] Turner, S. B. (2013). Shahram Akbarzadeh (2010) Challenging Identities: Muslim Women in Australia. With Foreword by Hanifa Deen. Melbourne University Press. Asian Journal of Social Science 41(2), 235-236.

[41] Vahed, G. (2008). Young Muslims in Brisbane: Negotiating Cultural Identity and Alienation. Journal of Social Sciences, Special Volume No. 1, 35-52.

[42] Yasmeen, S. (2002). Muslim Women as Citizens in Australia: Perth as a case study. In Y. Y. Haddad \& I. Smith Jane (Eds.), Muslim Minorities in the West: visible and invisible. Walnut Creek, Lanham, New York, Oxford: Altamira Press.

[43] Yasmeen, S. (2008). Understanding Muslim identities: From perceived relative exclusion to inclusion: Department of Immigration and Citizenship Canberra.

[44] Zine, J. (2006). Unveiled sentiments: Gendered Islamophobia and experiences of veiling among Muslim girls in a Canadian Islamic school. Equity \& Excellence in Education, 39(3), 239-252. 